\title{
Shakespeare under global lockdown: Introduction
}

\author{
Peter J. Smith \\ Nottingham Trent University, Nottingham, UK \\ Janice Valls-Russell
}

Centre national de la recherche scientifique (CNRS) and Université Paul-Valéry Montpellier 3, Montpellier, France

\section{Daniel Yabut}

Centre national de la recherche scientifique (CNRS) and Université Paul-Valéry Montpellier 3, Montpellier, France

Hamnet is closest so he goes to answer [a knock on the front door]. As it swings open, he cringes and yelps: on the doorstep is a terrifying sight, a creature from a nightmare, from Hell, from the devil. It is tall, cloaked in black, and in the place of a face is a hideous, featureless mask, pointed like the beak of a giant bird. [...] The spectre is speaking without a mouth, saying he will not come in, he cannot, and they, the inhabitants, are hereby ordered not to go out, not to take to the streets, but to remain indoors until the pestilence is past. (Maggie O'Farrell, Hamnet) ${ }^{1}$

It is the beginning of July as we write this introduction to our special section, 'Reviewing Shakespeare under Lockdown', which means that we are six months into the Covid-19 global pandemic. To date, over 11 million cases have been diagnosed, with more than 500,000 lives claimed by the coronavirus. We have yet to face the catastrophic damage inflicted on societies in other less evident ways, all of which we must come to grips with as we exit a sustained period of confinement. Unemployment is rising exponentially, education and travel are all but at a stand-still, and the future is bleak for millions of people worldwide, damaged in heretofore unthinkable ways by the highly contagious and as yet incurable virus.

In response to the outbreak, one by one, countries went into some form of 'lockdown', with citizens either recommended or enforced to stay at home and wear masks in public. Businesses, shopping centres, cafes, restaurants, sporting facilities, cinemas, theatres - in short, all 'non-essential' facilities, big and small, as well as schools and universities - emptied out. Streets, parks, and beaches were vacated, as people retreated to their homes. Comparisons to the 1918 influenza outbreak (which caused the death of 50 million people around the world) and, even more dramatically, the Black Death, whose progress - killing perhaps 200 million in Europe - Petrarch charted over almost three decades, have been abundant in the media. ${ }^{2}$ Horrific outbreaks of Ebola and severe acute respiratory syndrome (SARS), of which Covid19 is a strain, have occurred this side of the millennium; but these have been geographically contained and, in our lifetimes, there has been nothing on the scale or with the global reach of this coronavirus.

With uncanny foresight, Maggie O'Farrell's fictional biography of Shakespeare's doomed son (quoted above) was published in March. Acutely attuned to the boundlessness of maternal grief, this pensive novel, by turns tender and intense, in its final scene (which takes place in the Globe at a performance of Hamlet), suggests that art can provide some consolation. Indeed, it appears to be the case for many: though Covid-19 has caught the world by surprise, in sharp contrast to the opacity, indifference, fumbling, and sheer incompetence of quite a few governments, and in spite of anxieties over their futures, citizens have displayed remarkable maturity and resilience - most powerfully etched in collective memories in the videos of Italians singing on their balconies. 
One of the most unsettling effects has been a heightened awareness of our vital indebtedness to medical progress. While this is something of which patients suffering from cancer or other diseases are acutely aware, this was collectively experienced and tracked on social media across the planet: day by day, humankind monitored science in the making - and unmaking, as findings moved like Alice's queen, two steps forward, one step back, scientists disagreed, and an established journal like the Lancet retracted a published analysis regarding the efficacy of a popular treatment for the virus. ${ }^{3}$ The measles vaccine took over 10 years to develop, and we have been living with AIDS for four decades without, to date, a cure. Even if, and when, a vaccine against Covid-19 arrives, its effectiveness will rely upon the inoculation of perhaps 70 per cent of the world's population (six billion people). For O'Farrell, the future will necessitate a constant vigilance:

If this coronavirus crisis teaches us anything it is that nothing is stable, that our situation must be reassessed every day, sometimes every hour. [...] We will emerge from this but we will be different, depleted, forced to make ourselves anew. We will never be able to go back to a time before this pandemic, to a time of security and confidence, when we thought we were inviolate, immune. We will carry this with us, always; we will never be able to forget. ${ }^{4}$

In comparison to the enormity of the terrestrial changes brought about by Covid-19, anxiety about the future of the entertainment industry might seem small beer. Set alongside the impending recession of the world economy, the collapse of a few theatre companies ought not to cause too many sleepless nights. The resourcing of public health and essential economic stimuli ought to take precedence over the preservation of Waterloo's Old Vic, Paris's Le Théâtre des Halles, Milan's Piccolo Teatro, the survival of international festivals, such as those of Craiova, Gdánsk, or Avignon, and of smaller theatre companies around the world. And yet

In spite of the enormity of the implications of the so-called 'new normal', voices are still heard, and stories shared. Though theatres around the world have been, and remain, shuttered, it has not meant that the curtain has fallen on the performers, or that lively interval and post-show conversation has halted. Far from it. Footlights have made way for illuminated screens; floor boards have been swapped for Zoom and dedicated theatre streaming platforms, and front-of-house lobbies and cafes for Twitter and WhatsApp. The Royal Shakespeare Company (RSC), Cheek by Jowl, Comédie-Française, Théâtre Odéon de Paris, Kiev's Ivan Franko National Theatre, the Warsaw National Theatre, the Folger Shakespeare Library, and the New York Metropolitan Opera, are among many companies and venues that have offered free access to a myriad of productions from their archives. The BBC and other national television channels have screened recordings of previously archived performances; Spanish and French television have also made available adaptations of the classics (including Shakespeare), which were designed specifically for 'small-screen' format in the 1960s and 1970s (see Jesús Tronch's and Gaëlle Ginestet's respective reviews). Poznań's Asz.Teatr showcased on YouTube a Shakespearean medley of epilogues, soliloquies, and sonnets read by actors in their homes. Students from the drama school attached to the Teatro Stabile del Veneto presented and read sonnets from their residences (reviewed by Anna Maria Cimitile), while French actor-director Thomas Jolly read scenes, including Romeo and Juliet's balcony scene from his own balcony (see Rosalind Fielding's review). Patrick Stewart has been posting a sonnet-a-day on Twitter and Instagram; RSC artists have done the same in their social media channels. Thanks to the collective spirit of the global community, streaming options have ballooned to the point that for the avid theatre-watcher, there is simply not enough time in the day to take it all in. 
From behind closed doors, the actors of the Blackfriars Playhouse in Staunton, Virginia filmed their entire 'Renaissance season' in an almost empty theatre (see Lois Potter's review). Many artists have taken to social media, YouTube, or most prominently, the now-ubiquitous Zoom videoconferencing platform, to interact virtually with performers and engage with audiences across the internet. Veteran and new actors alike have taken to self-taping monologues, for established companies such as Hudson Valley Shakespeare Festival, or lending a hand to projects such as 'Quarantine Players', organised by the Guardian and Shakespeare's Globe, which brought together members of the public to read their favourite scenes alongside stage luminaries such as Roger Allam and Stephen Fry. ${ }^{5}$ Creation Theatre adapted their successful 2019 Oxford production of The Tempest to Zoom, with the virtual fourth wall broken in that audience members sat in the same 'meeting room', fully on display alongside the actors in panoramic mode. In Japan, Dainanasedai Jikkensitsu presented a play reading of Richard III on Zoom, streamed in 15-minute parts on YouTube (reviewed by Tomonari Kuwayama). The Italian company Ippogrifo Produzioni commissioned three-minute lockdown videos of classical plays, which included Shakespeare adaptations. ${ }^{6}$ Finally, new theatre troupes have been born in response to the pandemic. Rob Myles's weekly YouTube live series The Show Must Go Online features an ever-changing ensemble of Zoom performers of all levels from around the world, who stage entire plays or scenes from Shakespeare or a spin-off, such as William Shakespeare's Star Wars: Verily, A New Hope, adapted from the first of Ian Doescher's popular Shakespeare/Star Wars mashups. CtrlAlt_Repeat, which formed after the global collective's livestreamed Zoom performance of Midsummer Night Stream (reviewed by Colette Gordon), has since produced offerings such as As You Like It and The Importance of Bcc'ing Earnest.

In response to the threat of closures, theatre patrons, practitioners, and scholars have stepped up in droves. Campaigns have been launched to save theatres from the brink. One could for example observe viewers' generosity in the live commentary feed for each weekly NT Live broadcast, which has streamed a different show every Thursday at $7 \mathrm{pm}$ BST on YouTube, to help raise funds for the National Theatre (NT) and other participating theatres; a viewer even suggested that the 'NT at Home' programme should continue beyond the pandemic:

Please keep making your productions available online once Lockdown has ended with a minimum payment built in, some of us can never get to the theatre for health reasons, [or cannot] afford it, you are the nation's theatre, please earn some income whilst making your amazing work accessible to everyone. ${ }^{7}$

From 11 May to 2 June, Brave Spirits Theatre, which normally performs in Alexandria, Virginia, hosted on YouTube an online reading festival of English early modern history plays. London-based Jermyn Street Theatre's sonnet-a-day initiative has been featuring readings by drama students and professionals such as Olivia Colman, with scholars contributing glosses, available daily on Twitter, Instagram, and Facebook. On 23 May - just six days after The Stage and other news outlets announced the imminent danger facing Shakespeare's Globe - ten of the Globe's former MA students brought together an international cast of 200 volunteer readers, composed of early-career and professional actors, scholars such as Lois Potter and Stephen Greenblatt, and Shakespeare lovers, on Zoom for a 48-hour read-a-thon of 16 Shakespeare plays. The 'Read for the Globe' event was broadcast live on YouTube and raised over $£ 13,000$, smashing its original modest goal of $£ 5,000 .{ }^{8}$ Sam Mendes established the Theatre Artists Fund to aid practitioners, with Netflix making an initial $£ 500,000$ donation. ${ }^{9}$ Finally, two days after a number of theatres across the UK, including the Royal Lyceum Theatre Edinburgh and Lyric Belfast, were wrapped in bright pink barrier tape carrying 
messages of support, ${ }^{10}$ the UK government unveiled a $£ 1.57 \mathrm{bn}$ rescue package for the arts and heritage sectors. ${ }^{11}$ Across the Channel, in May, the French government extended its special $€ 7 \mathrm{bn}$ unemployment benefit fund over the next 12 months, which was established in March in response to the pandemic to support small companies and independent contractors, including theatre practitioners. ${ }^{12}$

Despite these offerings and measures, it remains the hard truth that theatres have been deprived of their primary revenue streams. Leicester Haymarket Theatre is already in liquidation while Nuffield Southampton Theatres is in administration; the Royal Exchange in Manchester, the NT, and even the venerable UK theatre trade paper The Stage (publishing since 1880) have announced major cuts to staff; and countless others are in imminent danger of closing their doors forever. Theatre impresario Sonia Friedman reports that 70 per cent of UK performing arts companies will be out of business before the end of the year, with insolvency and the possibility of permanent closure affecting more than 1,000 UK theatres - and this is just one national example. ${ }^{13}$ As director Richard Eyre puts it, 'Live theatre is at war with lockdown. ${ }^{14}$

Theatre is both a necessity and a luxury, to echo Voltaire's 'Le superflu, chose très nécessaire.' It is a necessity to the hundreds of thousands of playwrights, stage managers, lighting designers, actors, sound designers, publicity agents, marketing departments, boxoffice staff, education and outreach practitioners, security workers, bar staff, cleaners, paintframe, props, production, literary advisors, theatre reviewers and journalists. It is a necessity to national economies, generating income for treasuries, and vital to cities and out-of-the-way places that factor festivals and other cultural events into their touristic seasons. ${ }^{15}$ It is, simply, a necessity to our human condition. Florence March, one of the editors of this journal and a specialist of the Avignon Festival (a crucial hub of the papal city's economy), recalls how its founder, Jean Vilar, considered that the theatre was as indispensable to humankind as water and electricity. ${ }^{16}$

Nevertheless, hope and optimism are shared by theatre communities. Simon Russell Beale points out that - for Shakespeare's contemporaries - lockdown (including the closure of the theatres) was par for the course. Optimistically perhaps (but he seemed to be proved right when Parisians made a rush for the café terraces as soon as they reopened in June), he anticipates the triumph of conviviality over the physical isolation imposed by social distancing and the degree to which live performance is dependent upon such a communality:

You wonder how people were coaxed back into the theatre [following a plague outbreak in 1606] in Shakespeare's time. I am bullish though about people's fundamental need for contact, or at least physical proximity, whether they are watching a play, a concert or a firework show. We need that sense of community. ${ }^{17}$

Jean Varela, the director of Montpellier's Printemps des Comédiens, France's second largest theatre festival after Avignon (both festivals were cancelled), is equally hopeful. During lockdown, the Montpellier festival ran a weekly radio program bringing together theatregoers, practitioners, and academics for commissioned readings of scenes from Shakespeare and other dramatists, and talks on topics such as disease, masques, silence, and resilience. Nevertheless, a period of quiet before the theatres can reopen is necessary, in Varela's view, as a form of collective mourning/tribute for the victims of the pandemic: 'we are all Antigone families', he said, referring to those who have been unable to attend funerals of their beloved. ${ }^{18}$ Spain was one of the rare countries to introduce a period of mourning for its victims.

In this special section, seasoned and early-career reviewers offer critiques of streamed productions, but also share a more personal perspective of their diverse viewing situations, and notably, experiences with livestreams. Some of our veteran contributors had never seen an 
online production until faced with reviewing one, while some first-time critics were well versed in digital viewing. The 37 authors of 32 reviews from 14 countries chose what they wished to critique, covering productions from around the world in 13 different languages. NT Live theatre streams have enabled viewers to catch shows such as the NT's Twelfth Night with Tamsin Greig (reviewed by Delilah Bermudez Brataas), the Donmar Warehouse's The Tempest starring Harriet Walter (reviewed by Hannah Mullaghy), and Coriolanus featuring Tom Hiddleston (reviewed by Peter J. Smith) - the latter offering multitasking viewers the opportunity to watch the 2015 proceedings/performance on YouTube alongside live Instagram commentary by Hiddleston, Deborah Findlay (Volumnia), and director Josie Rourke. Twitter watch parties were organised around live streams, such as for Schaubühne Berlin offerings of Thomas Ostermeier's Richard III and Hamlet (the latter reviewed by Eoin Price), and for Cheek by Jowl's Winter's Tale (reviewed by Cécile Decaix). Dana Monah congregated virtually with thousands of viewers on Facebook for Craiova International Shakespeare Festival's streaming of Silviu Purcărete's Ubu Rex with Scenes from Macbeth, as did Mădălina Nicolaescu and Oana-Alis Zaharia, who review three productions of Measure for Measure staged over a decade. Jacek Fabiszak and Anna Wołosz-Sosnowska joined viewers online for a one-off streaming of a ballet adaptation of The Tempest by Warsaw's Teatr Wielki - Opera Narodowa. Sarah Olive was at the monitor for Vietnam Youth Theatre's Macbeth at the Nội Opera House, while Sarah Temmar reported on an Algerian Twelfth Night. In Zaporizhzhia, Ukraine, Bohdan Korneliuk and Daria Moskvitina convened remotely to watch a national production of The Tempest and a Moldovan Richard III. For some, watching outdoor performances on a screen indoors fosters a sense of nostalgia for the 'old' world (see the reviews by Richard J. Larschan and Laurence N. Moscato, and by Tomonari Kuwayama).

While the coronavirus may have brought the theatrical and scholarly communities together in unexpected ways, it has also created and exposed disturbing divisions - none more significant, perhaps, than the death of George Floyd at the hands of a white police officer on 25 May 2020 in Minneapolis. Occurring after all of the reviews were submitted, but during the writing of this Introduction, this tragedy has enveloped the world and has already proven to be a critical cultural turning point that has exposed uncomfortable truths: Black voices have been marginalised and excluded from positions of power and influence in every walk of life; in the US, the UK, France and elsewhere, Black, Asian and other racial and ethnic communities seem to have paid a high toll in terms of Covid-19-related deaths.

In spite of the difficulties theatres worldwide have been going through, ethical values have continued to prevail. Theatres and festivals have shown a high degree of involvement with the community, well beyond their efforts to stay in touch with their patrons. Educational material and productions for young audiences such as Justin Audibert's Macbeth (reviewed by Agnès, Esther, and Héloïse Lafont) have proved invaluable resources for teachers, who interacted with their students in new ways, as Coen Heijes reports. In the United States, Acting for a Cause, in partnership with Hollywood's Entertainment Industry Foundation (EIF), addressed a double agenda, responding to the pandemic and the institutionalised murder of Black people. ${ }^{19}$ Such forms of engagement acquired even greater topical relevance after Floyd's murder. As hundreds of thousands of people around the world defied lockdown and chose, reversing O'Farrell's words at the beginning of this Introduction, to take to the streets and not remain indoors until the pestilence is past, in order to protest against that other, systemic, pestilence, racism, numerous theatres and practitioners have voiced their support for Black Lives Matter, with some, such as the National Theatre of Scotland and New York's Red Bull Theater, putting their digital programmes temporarily on pause in a symbolic gesture to recognise the movement.

In its play-reviewing section, Cahiers Élisabéthains has long encouraged three kinds of conversation. First, it has set side by side academic and non-academic voices - from the 
universities and sectors such as schools and the theatre industry. Second, Cahiers has a proven track record of introducing a diversity of up-and-coming international voices, graduate students, or early-career academics - alongside experienced reviewers. Third, Cahiers is committed to offering reviews of productions from beyond the Anglophone world. The reviews that follow represent, we feel, the very best of these three conversations, and a powerful sense of sharing an unprecedented global experience runs through this collection. In 2019 the editors celebrated the publication of the $100^{\text {th }}$ issue of the journal in a letter to its readers and contributors with the hope that 'you continue to be part of the Cahiers community'. Editing this unique section, under unique circumstances, only reinforces the strength of that hope. Community is dear to theatre-making and theatre-going experiences, to our sharing of those experiences, and essential to our personal sense of civic engagement. As guest-editors of this section, and individuals, we look forward to the day when such community can, once again, be taken for granted.

'If When we do meet again, why, we shall smile'. (Julius Caesar, 5.1.118)

\section{Acknowledgements}

The authors are immensely grateful to Teunkie Van Der Sluijs and Mya Lixian Gosling for allowing us to publish samples of their work.

\section{Declaration of conflicting interests}

The authors declared no potential conflicts of interest with respect to the research, authorship, and publication of this article.

\section{Funding}

The authors received no financial support for the research, authorship, and publication of this article.

\section{Notes}

\footnotetext{
${ }^{1}$ Maggie O'Farrell, Hamnet (London: Tinder Press, 2020), p. 146.

${ }^{2}$ See for example, Paula Findlen, 'Petrarch's Plague: Love, Death, and Friendship in a Time of Pandemic, Public Domain Review, 11 June 2020, www.publicdomainreview.org/essay/petrarchs-plague (accessed 16 June 2020).

${ }^{3}$ Mandeep R. Mehra et al., 'RETRACTED: Hydroxychloroquine or chloroquine with or without a macrolide for treatment of COVID-19: a multinational registry analysis', The Lancet, 22 May 2020, www.thelancet.com/journals/lancet/article/PIIS0140-6736(20)31180-6/fulltext (accessed 16 June 2020).

${ }^{4}$ Maggie O'Farrell, 'How disease has shaped life as we know it', Guardian, 6 April 2020, www.theguardian.com/books/2020/apr/06/maggie-ofarrell-how-disease-has-shaped-life-as-we-know-it (accessed 16 June 2020).

${ }^{5}$ Chris Wiegand, 'Quarantine Players: Stars and theatre fans unite to perform Shakespeare solos', Guardian, 23 April 2020, www.theguardian.com/stage/2020/apr/23/quarantine-players-theatre-shakespeare-solos-globe (accessed 3 July 2020).

${ }^{6}$ See www.facebook.com/pippogrifi (accessed 16 June 2020).

7 'Official Small Island / Free National Theatre at Home Full Performance', National Theatre, 25 June 2020, www.youtube.com/watch?v=pac-Furijsw (accessed 25 June 2020; video no longer available).

${ }^{8 ‘}$ Former King’s students raise over $£ 13,000$ for Shakespeare’s Globe’, King’s College London, 29 May 2020 , www.kcl.ac.uk/news/former-kings-students-raise-over-13000-for-shakespeares-globe (accessed 20 June 2020). ${ }^{9}$ Chris Weigand, 'Sam Mendes launches fund for theatre workers hit by Covid-19 crisis', Guardian, 5 July 2020, www.theguardian.com/stage/2020/jul/05/sam-mendes-the-theatre-artists-fund-covid-19-netflix (accessed 5 July 2020).
} 
${ }^{10}$ Closed theatres wrapped in pink ribbon messages of support', $B B C, 3$ July 2020 , www.bbc.com/news/entertainment-arts-53276472 (accessed 3 July 2020).

11 'Coronavirus: emergency money for culture "won't save every job"', $B B C, 6$ July 2020, https://www.bbc.com/news/entertainment-arts-53302415 (accessed 6 July 2020).

12 'Macron announces extra aid for French arts sector battered by Covid-19 crisis', France 24, 6 May 2020, https://www.france24.com/en/20200506-macron-announces-extra-aid-for-french-arts-sector-battered-by-covid19-crisis (accessed 6 July 2020).

${ }^{13}$ Sonia Friedman, 'Theatre stands on the brink of ruin', Telegraph, 21 May 2020, www.telegraph.co.uk/theatre/what-to-see/theatre-stands-brink-ruin/ (accessed 16 June 2020).

${ }^{14}$ Susannah Clapp, 'The future of the arts: "Online theatre is a skeleton of the thing itself", Guardian, 21 June 2020, www.theguardian.com/stage/2020/jun/21/the-future-of-the-arts-online-theatre-is-a-skeleton-of-the-thingitself (accessed 3 July 2020).

${ }^{15}$ In 2018, the sale of 34 million tickets in the UK resulted in an income of $£ 1.28$ billion. In London's West End alone, $£ 765$ million of box-office takings generated $£ 127$ million for the treasury in VAT

(www.uktheatre.org/theatre-industry/news/2018-sales-data-released-uk-theatre-and-society-of-london-theatre/). In France the cultural industry represents 2.5 per cent of the country's GNP and 2.2 per cent of jobs (www.franceculture.fr/emissions/la-question-du-jour/coronavirus-quelles-consequences-economiques-pour-lesecteur-culturel) (both links accessed 16 June 2020).

16 'Feuilleton \#9, Résilience', Radio Web Printemps, Printemps des comédiens, 27 May 2020, www.printempsdescomediens.com/radioweb-pcm-2020-feuilleton-001/ (accessed 16 June 2020).

${ }^{17}$ Vanessa Thorpe, "'It's a horrible time": why Simon Russell Beale fears for future of theatres', Guardian, 19 April 2020, www.theguardian.com/stage/2020/apr/18/its-a-horrible-time-why-simon-russell-beale-fears-forfuture-of-theatres (accessed 20 June 2020).

18 'Feuilleton \#8, Sound of Silence', Radio Web Printemps, 20 May 2020, www.printempsdescomediens.com/ radioweb-pcm-2020-feuilleton-001/ (accessed 16 June 2020).

${ }^{19}$ Acting for a Cause, www.actingforacause.org (accessed 16 June 2020).

\section{Author biographies}

Peter J. Smith is co-editor-in-chief of Cahiers Élisabéthains and Reader in Renaissance literature at Nottingham Trent University.

Janice Valls-Russell reviews regularly for Cahiers Élisabéthains. She is co-editing with Boika Sokolova a volume on Performing Shakespeare's Strangers in $21^{\text {st }}$-century Europe. Daniel Yabut is a theatre practitioner, Performance Reviews editor for Cahiers Élisabéthains, and a research associate for CNRS. 